\title{
Analisis Strategi Marketing Public Relation Kedai Kopi Sijoko
}

\author{
Ani Indriyani', Diah Ayu Candraningrum²* \\ ${ }^{1}$ Fakultas Ilmu Komunikasi, Universitas Tarumanagara, Jakarta \\ Email:ani.915170176@stu.untar.ac.id \\ ${ }^{2}$ Fakultas Ilmu Komunikasi, Universitas Tarumanagara, Jakarta* \\ Email:diahac@fikom.untar.ac.id
}

Masuk tanggal : 15-12-2021, revisi tanggal : 06-01-2022, diterima untuk diterbitkan tanggal : 16-01-2022

\begin{abstract}
Indonesia is currently faced with a crisis due to the health of the Covid-19 The Implementation of Large-Scale Social Restrictions (PSBB) is a strong indicator of current problems. This situation has an impact on society in general and many Small and Medium Enterprises (UKM) in particular have turned to other businesses and even closed their businesses. One of these small and medium enterprises is the Coffee Shop. As a coffee shop, Sijoko coffee is also experiencing the same problem. However, what's interesting about the Sijoko coffee shop is that it still exists today. In this case, this coffee shop can be categorized as a street coffee shop. he question is, what and how are the marketing public relations strategies used by the Sijoko coffee shop so that they can face competition in the research approach using a qualitative descriptive approach. While the research method using sampling is purposive technique. Collection of this pandemi situation. currently the phenomological method. Techniques are carried out by observation, interviews, and documentation. Data analysis used qualitative data analysis and data validity techniques. The results showed that the marketing strategy of the Sijoko coffee shop public relations in increasing Customer Engagement was local strategy (coffee flavor image), Strategy Push and Strategy Pass with the form of word of mouth communication and interpersonal communication.
\end{abstract}

Keywords: coffee shop, customer engagement, marketing public relations strategy

\begin{abstract}
Abstrak
Indonesia saat ini diperhadapkan dengan krisis kesehatan akibat pandemi covid-19. Penerapan Pembatasan Sosial Berskala Besar (PSBB) adalah indikator kuat permasalaan saat ini. Situasi ini berdampak pada masyarakat umumnya dan Usaha Kecil dan Menengah (UKM) khusus banyak yang berpaling ke usaha lain bahkan menutup usahanya. Salah satu usaha kecil dan menengah tersebut yakni Kedai Kopi. Sebagai salah satu kedai kopi, kopi Sijoko juga mengalami permasalah yang sama. Namun, yang menarik dari kedai kopi Sijoko adalah hingga saat ini masih eksis. Padahal kedai kopi ini dapat dikategorikan kedai kopi jalanan. Pertanyaannya, apa dan bagaimana strategi marketing public relations yang digunakan kedai kopi Sijoko sehingga dapat menghadapi persaingan dalam situasi pandemi saat ini. Pendekatan penelitian menggunakan pendekatan deskriptif kualitatif. Sedangkan metode penelitian menggunakan metode fenomelogi. Teknik pengambilan sampel adalah teknik purposive. Pengumpulan dilakukan dengan observasi, wawancara, dan dokumentasi. Analisis data menggunakan analisa data kualitatif serta teknik keabsahan data. Hasil penelitian menunjukkan bawa strategi marketing public relations kedai kopi sijoko dalam meningkatkan customer engagement adalah lokal strategi (citra rasa kopi), push strategy dan pass strategy dengan bentuk komunikasi word of mouth dan komunikasi interpersonal.
\end{abstract}

Kata Kunci: customer engagement, kedai kopi, strategi marketing public relations 


\section{Pendahuluan}

Siapa yang menyangka terjadi krisis dunia saat ini? Krisis kesehatan yang telah menelan begitu banyak nyawa manusia, ekonomi dunia ambruk karena kegiatan ekonomi menjadi lumpuh. Hal ini ditandai dengan lock down di beberapa negara dan juga Penerapan Pembatasan Sosial Berskala Besar (PSBB). Fakta-fakta tersebut menunjukkan betapa virus corona sangat mematikan.

Salah satu usaha kecil dan menengah tersebut adalah kedai kopi. Berdasarkan data yang peneliti rilis dari https://katadata.co.id/dijelaskan bahwa pandemi memukul industri kopi dalam negeri. Namun, potensinya ke depan masih besar untuk turut menggerakkan perekonomian nasional. Hal itu berarti bisnis kedai kopi akan terus meningkat setelah pancemi covid-19.

Peninkatan usaha kedai kopi tidak dapat dilepaskan dari keterjalinan pemilik dengan pelanggan. Menjalin hubungan dengan pelanggan berarti mendapatkan dan mempertahankan hubungan dengan pelanggan secara berkesinambungan. Paradigma tersebut dinamakan relationship marketing (Haryono, 2010). Dasar pemikiran dalam praktik pemasaran tersebut adalah bahwa jalinan hubungan dengan pelanggan itu dianggap sangat menghemat biaya dibandingkan dengan mencari pelanggan baru atau mendapatkan pelanggan lama yang sudah putus hubungan (Haryono, 2010).

Kotler (dalam Rachman,2017) mengemukakan bahwa saluran komunikasi personal berupa ucapan dari mulut ke mulut (word of mouth) dapat menjadi metode promosi yang efektif karena pada umumnya disampaikan dari konsumen oleh konsumen dan untuk konsumen.

Singkatnya, strategi yang spesifik akan lebih efektif dari marketing public relations dalam mempertahankan dan meningkatkan customer engagement dari kedai kopi. Bertolak dari sini, peneliti akan menganalisis strategi marketing public di kedai kopi Sijoko untuk membangun engagement.

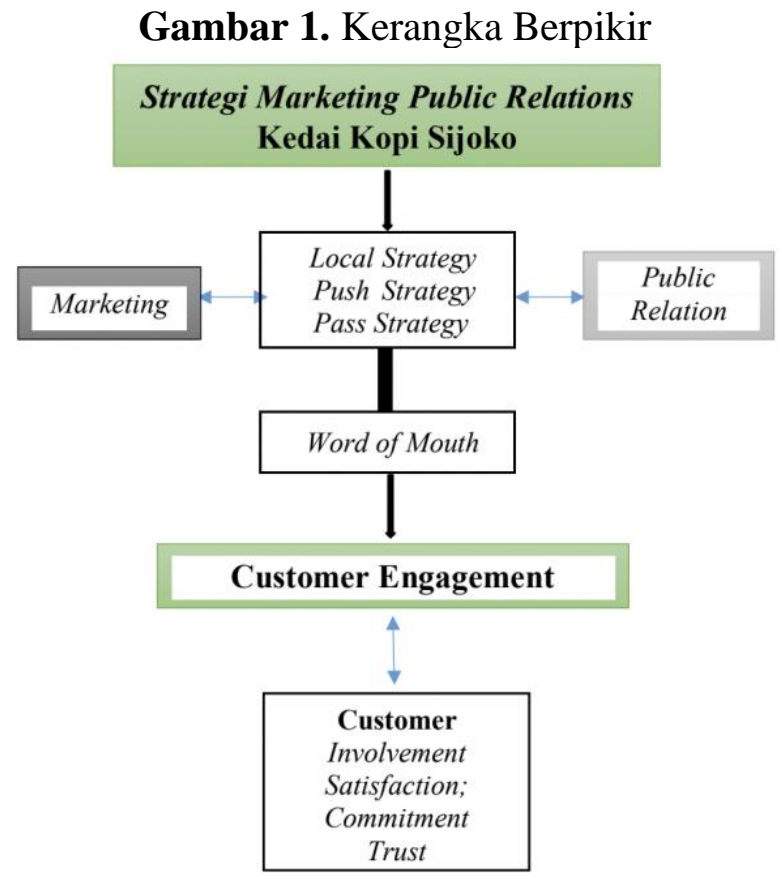

Sumber: Dokumentasi Pribadi 
Ani Indriyani, Diah Ayu Candraningrum: Analisis Strategi Marketing Public Relation Kedai Kopi Sijoko

\section{Metode Penelitian}

Metode penelitian yang digunakan untuk menggali eksistensi kedai kopi Sijoko dalam persaingan saat ini adalah metode fenomenologi. Subyek penelitian kualitatif adalah pelaku atau aktor yang diteliti sesuai masalah penelitian (Sugiyono, 2015). Adapun subyek dalam penelitian ini yakni pemilik kedai dan customer. Sedangkan obyek penelitian adalah situasi sosial di kedai kopi Sijoko yakni suatu keadaan dimana kedai kopi Sijoko mampu bertahan dalam situasi saat ini. Sugiyono (2015) menjelaskan bahwa situasi sosial merupakan inti dari obyek penelitian kualitatif dengan 2 (dua) elemen utama yakni tempat (place) dan aktivitas (activity) yang berintegrasi secara sinergis.

a. Metode Pengumpulan Data

Metode wawancara mendalam, observasi mendalam dan dokumentasi

b. Teknik Pengolahan dan Analisa Data

Teknik analisis data menggunakan analisis data deskriptif kualitatif

c. Teknik Keabsahan Data

Teknik pemeriksaan keabsahan data bertujuan agar hasil penelitian dapat dipertanggung jawabkan dari segala sisi. Penelitian ini menggunakan teknik keikutsertaan peneliti untuk membangun kepercayaan para subjek dan teknik triangulasi dimana peneliti mengkonfirmasi hasil wawancara, observasi dengan triangulator.

\section{Hasil Temuan dan Diskusi}

Setelah melewati serangkai kegiatan penelitian wawancara dan observasi baik dengan pemilik, pelanggan dan triangulator maka berikut ini dipaparkan temuan yang diperoleh yakni:

Dalam temuan dan anlisis si pemilik kedai kopi sijoko adalah center of point dari seluruh aktivitas baik itu di kedai kopinya hingga strategi-strategi yang di gunakannya dalam pengenalan kedai kopi Sijoko. Pertanyaan sentral dalam penelitian ini adalah "bagaimana strategi marketing public relations word of mouth di kedai kopi Sijoko dalam meningkatkan customer engagement?"

Dalam analisis yang dilakukan peneliti berdasarkan hasil wawancara, observasi dan dokumentasi maka peneliti menemukan bahwa strategi marketing public relations word of mouth yang dipraktikkan selama ini di kedai kopi Sijoko untuk meningkatkan customer engagement adalah lokal strategi, strategi Push dan Pass. Ketiga strategi ini berlangsung dengan sangat baik.

Pertama adalah trategi lokal. Si pemilik kedai kopi Sijoko sangat mempertahankan citra rasa kopinya. Dan untuk mempertahankan citra rasa kopinya maka takaran atau racikan kopinya selalu menggunakan timbangan digital. Hal ini sangat penting karena customer menghendaki rasa kopi yang diminumnya selalu sama rasanya. Dimensi customer yang dilaksankan yakni dimensi kepuasan dan kepercayaan pelanggan. Strategi ini oleh peneliti merupakan strategi yang cukup baik yang dipraktekan oleh pemilik kedai kopi. Karena dengan strategi ini ia mengetahui kelebihan dan kekuarangan dari kedai kopi miliknya. Strategi ini dalam ilmu komunikasi disebut sebagai komunikasi interpersonal.

Selanjutnya adalah strategi push. Dalam menjalankan strategi ini, si pemilik memberikan diskon kepada setiap pembeli yang baru sekali beli kopi ditempatnya. Promosi yang sama akan diberikan kepada pelanggan yang sudah 2 atau 3 kali datang 
membeli dan meminum kopi di kedainya. Strategi ini menunjuk pada dimensi komitmen baik dari si pemilik kopi maupun pelanggan. Strategi ini menurut hemat peneliti digunakan pemilik kedai kopi sebagai strategi lanjutan dari strategi lokal di atas. Strategi ini lasim digunakan oleh pebisnis kuler lainmya. Biarpun demikian strategi ini tetap merupakan peluang untuk menperoleh dan mempertahankan pelanggan customer engagement yang telah ada.

Yang ketiga adalah strategi pass. Untuk mengetahui seberapa dekat customer dengan kedai kopi miliknya maka dibentuk grup WhatsApp kedai kopi sijoko. Dengan adanya grup ini si pemilik selalu menawarkan weekend bersama setiap hari sabtu sampai minggu jalan-jalan ke Bogor atau Bandung. Tujuannya, si pemilik bisa lebih banyak meminta saran dari customer tentang perkembangan kedai kopinya. Selainnya si pemilik bisa lebih mengakrabkan dirinya dengan pelanggannya. Si pemilik juga membangun komunikasi interpersonal dengan pelanggannya. Strategi ini menunjuk pada pemenuhan dimensi keterlibatan dan kepercayaan palanggan terhadap kedai kopi Sijoko.

Strategi ini oleh peneliti merupakan strategi yang cukup baik yang dipraktekan oleh pemilik kedai kopi. Karena dengan strategi ini ia mengetahui kelebihan dan kekuarangan dari kedai kopi miliknya. Strategi ini dalam ilmu komunikasi disebut sebagai komunikasi interpersonal.

Sebagaimana telah disinggung pada temuan dan analisis di atas, Marcel dan Aliyah sebagai pelanggan baru mengetahui dan direkomendasikan oleh teman-teman mereka (pelanggan kedai kopi Sijoko). Hal ini berarti kedai kopi Sijoko telah memiliki customer engagement dan terus berusaha meningkatkannya lewat strategi marketing public relations. Di samping strategi-strategi yang jitu di atas, bentuk komunikasi yang dijalankan turut serta mendukung word of mouth. Bentuk komunikasi ini sangat berperan mengingat pemilik kedai kopi Sijoko berhenti menggunakan media sosial sebagai sarana promosi dan penjualan. Sebagaimana yang diungkapkan oleh triangulator bahwa komunikasi word of mouth sebagai bentuk marketing adalah yang terbaik.

\section{Simpulan}

Hasil penelitian menunjukkan bahwa strategi marketing public relations kedai kopi Sijoko yang selama ini dipraktikkan adalah local strategy, push strategy dan pass strategy. Ketiga strategi ini mampu mempertahankan dan meningkatkan customer engagement. Hal ini dapat terlihat dari kedua pelanggan baru yang merupakan rekomendasi dari customer tetap.

Ketiga strategi tersebut dapat berjalan dengan baik karena bentuk komunkasi yang dibangun si pemilik kedai. Bentuk komunikasi yang dimaksud yakni komunikasi word of mouth dan komunikasi interpersonal.

\section{Ucapan Terima Kasih}

Peneliti ingin mengucapkan terima kasih kepada Fakultas Ilmu Komunikasi Universitas Tarumanagara, narasumber, serta semua pihak yang turut membantu peneliti sehingga penelitian ini dapat diselesaikan. 
Ani Indriyani, Diah Ayu Candraningrum: Analisis Strategi Marketing Public Relation Kedai Kopi Sijoko

\section{Daftar Pustaka}

Haryono, Tulus. 2010. Pentingnya Menjaga Dan Meningkatkan Hubungan Baik Dengan Konsumen Dalam Masa Krisis. Jejak. 3 (1). 75-82.

Peluang Wanginya Industri Kopi Indonesia Usai Pandemi - Analisis Data Katadata. (n.d.). Retrieved November 5, 2020, from https://katadata.co.id/muhammadridhoi/analisisdata/5fca6227da8b9/peluangwanginya-industri-kopi-indonesia-usai-pandemi

Rachman, Raniawati \& Totok Wahyu Abadi. 2017. Komunikasi Word Of Mouth Dan Keputusan Pembelian Batik Bangkalan. Jurnal Aspikom. 3(2). 285-295

Sugiyono. (2015). Metode Penelitian Administrasi. Cetakan Ke-20. Alfabeta. Bandung. 